Africa, C. \& Mutizwa-Mangiza, S. (2017). The need for a new language? How historically disadvantaged institutions grapple with the effects of labelling in higher Education: the case of the University of the Western Cape. Politikon. http://dx.doi.org/10.1080/02589346.2018.1418213

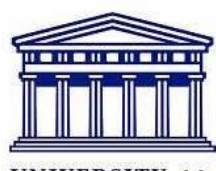

\title{
The need for a new language? How historically disadvantaged institutions grapple with the effects of labelling in Higher Education: the case of the University of the Western Cape
}

\author{
Cherrel Africa and Shingai Mutizwa-Mangiza
}

\begin{abstract}
Tertiary institutions in South Africa have been dichotomised through the colonial structure and apartheid which sought to subjugate some institutions and elevate others. Not only have historically disadvantaged institutions (HDIs) faced a set of deep material difficulties, they have also had to grapple with the negative implications of naming. Using the work of Stryker and Burke as well as Bourdieu, this article interrogates the complexities of the HDI label for the University of the Western Cape. This is a complex issue because the same label can simultaneously provide access to state resources and inhibit opportunities from potential sponsors and employers. Unlike individuals who can hold multiple identities, institutions are expected to embrace a particular identity. Our conclusion is that we need to open the conversation about institutional labelling and develop a new language to describe former HDIs which should ideally acknowledge their difficult history without perpetuating stigma.
\end{abstract}

\section{Introduction}

Labels are powerful and labelling is particularly salient in the South African context. Labelling is a 'process by which policy agendas are established and more particularly the way within which, people conceived as objects of policy are defined in convenient images' (Wood 1985, 1). The apartheid government in South Africa devised a complicated legislative system which was centred on labelling people in racial terms and the construction of associated racial identities. Indeed, apartheid's complex system epitomised the colonial structure outlined by Mudimbe (1988). Drawing on Christopher (1984), Mudimbe $(1988,2)$ argues that 'the domination of physical space, the reformation of natives' minds, and the integration of local economic histories into the Western perspective'... 'constitute what might be called the colonizing structure, which completely embraces the physical, human and spiritual aspects of the colonizing experience'. Mudimbe (1988, 4) further argues that because of the colonizing structure, a dichotomizing system has emerged'. According to Mudimbe, value is established within this dichotomising logic where one side of the binary is valued and the other side is devalued. In South Africa this process of othering extended to the creation and labelling of institutions of higher education. Historically disadvantaged institutions (HDIs) were established under apartheid to service the educational 'needs' of the former 'Bantu 
Homelands' (Subotzsky 1997). In particular, the way in which tertiary institutions were established and labelled extended the dichotomous language of othering where stark contrasts were created between institutions. In this process, some institutions were valued and others aspired to become like them. In democratic South Africa, constructs such as HDI perpetuate this dichotomising system and binary language.

To an extent, institutions have been forced to carry these labels into the democratic era given the complexities of attempting to address the injustices of the past without resorting to apartheid-era racial constructs. These labels become deep-rooted and become synonymous with particular institutions.

Institutional labels in South Africa are complicated to resist because they are bound both to access to state resources and reputational issues around 'excellence' and 'prestige'. In this article, our purpose is to consider the experience of one university, which was created for a particular racialised purpose and labelled as an HDI. It aims to provide an insider perspective on the complexities of grappling with an institutional identity and hopes to provide the basis for posing questions about the impact of institutional labelling. We argue that it is time to develop new terminology that affirms institutional accomplishments while also recognising challenges from the past.

The power of naming: identity, positionality and symbolic power There is a significant body of theory and research on the concept of self-fulfilling prophecies in which individuals change their conception of themselves based on the labels assigned to them. Becker (1963), Rosenthal, Jacobson, and Deutsch (1968) and Lemert (1974) highlight the impact that labelling has on the individual not on only in terms of psychological health, but also in terms of influencing behaviour. Stryker and Burke (2000) theorise that roles are primarily external involving linked positions within a social structure while identity is primarily internal, consisting of internalised meanings and expectations associated with a role. According to Stryker and Burke, social roles are seen as expectations attached to positions in networks of relationships while identities, on the other hand, are internalised role expectations. They take a situated identity perspective, which recognises the complexity of contemporary society in which people typically hold multiple identities, and argue that each role is embedded in one or more groups that provide context for the meanings and expectations associated with that role. A mismatch between identity and role expectations results in negative emotions. In identity theory, the self is reflexive in that it can see itself as an object and classify and name itself in particular ways.

Although these theories focus on how labelling affects individuals, we can look to the theoretical lens to assist us in understanding the nature of labelling for institutions. In this regard, Stryker and Burke only take us so far and a useful supplement is provided by Pierre Bourdieu. Bourdieu helps us to move beyond only looking at the impact of labelling, as his theory also considers issues of power and recognises the complexities of institutional identity. Bourdieu contends that there is struggle over what he terms as the 'monopoly of legitimate naming' (Bourdieu 1991, 239). This struggle is situated between the 'official', that 
is, those agents who possess an authority delegate to them by the state and autonomous agents, namely those individuals who are subjected to the bureaucratic power of the state (Bourdieu 1991).

Bourdieu contends that the 'monopoly of legitimate naming' or the right to confer legitimate identities over agents or subjects is the exclusive preserve of the 'official' or what we understand as authority. In Bourdieu's view, this 'monopoly over legitimate naming' serves two main purposes. The first, which he terms as the 'management of scarcity', essentially constitutes a mechanism through which authority regulates the distribution of resources in society. Central to this notion is that idea that through designation of particular identities, 'officials' are able systematically distribute scarce resources on the basis of perceived needs. He says

The management of names is one of the instruments of the management of material scarcity, and the names of groups, especially of professional groups, record a particular state of struggles and negotiations over the official designations and the material and symbolic advantages associated with them. (Bourdieu 1991)

Secondly, the right to partake in 'official' name giving is also a means through which officials are able to establish identities that can be recognised by all, such that

the official naming or the title or qualification, which like and educational qualification is valid on all markets and which an official definition of one's official identity saves it bearers from the symbolic struggle of all against all by establishing the authorized perspective, the one recognized by all and thus establishing the authorized perspective. (Bourdieu 1991)

Designated identities and 'naming' broadly speaking can not only establish social hierarchies but according to Bourdieu can also, in the case of authorised personnel or entities (i.e. those authorised to partake in 'naming'), produce 'symbolic violence' (Bourdieu 1991, 230). However, Bourdieu also asserts that agents are not merely passive recipients of official designations and are to a degree conscious of the hierarchies produced by naming and the material implications that various designations may assume. Accordingly, agents are able to exploit the perceived symbolic benefits associated with 'naming' strategically. In instances where certain named categories assume negative consequences, he states that agents may opt to occupy certain ambiguous categories in an effort disassociate themselves from the negative connotations associated with particular designations. He does, however, note that the more powerless these agents are the less authorised they are at acquiring the recognition they desire, the 'more concerned' they become with the acquisition of that recognition. 


\section{Contextual background: the University of the Western Cape's resistance to its ascribed role}

As Stryker and Burke (2000) indicate, identity is primarily internal, consisting of internalised meanings and expectations associated with a role while social roles are seen as expectations attached to positions in networks of relationships. The University of the Western Cape (UWC) has a long history of challenging the role ascribed to it by society and the state. The university was established in 1959 by the apartheid government, ostensibly to provide training for middle to lower tier occupational positions among the 'Coloured' community in the Western Cape Province and also as part and parcel of the policy of 'separate development' (see Kraak 2009). Wolpe $(1995,283)$ indicates that although the university was not created to produce the human resources required for the functioning of the Bantustans and was situated, as it still is, in an urban environment, nevertheless it was designed to perform a specific role in the reproduction of apartheid, namely, the provision of human resources to meet the needs of the coloured people as defined by the apartheid state, and in accordance with the racial stratification system of the prevailing social order.

Thus, the university was created for a particular racially informed purpose that espoused wider expectations and perceptions of the university. The university was initially established as a constituent college of the University of South Africa (UNISA), with limited autonomy. The limited autonomy of the institution in its earlier days could be attributed to the composition of its academic board, which was comprised largely of white conservative sympathisers of the National Party (Kraak 2009). However, following its designation as a formal university in 1970, the university underwent a period extensive transformation that resulted in greater academic autonomy and the appointment of a black rector in the form of Professor Richard van der Ross (Kraak 2009).

Clearly then, there was a mismatch between the role allocated to the university and the identity it sought to shape. Not only did the institution successfully resist a label and role that it found to be illegitimate, it also leveraged the debate to challenge power dynamics in South Africa. On 22 October 1982, the university published a mission statement that rejected key elements of the state's definition of the university's role and set new objectives for the institution. Wolpe indicates that in the ensuing years, the mission statement was translated into specific policies which began to change the character of the university (1995, 283). The formal rejection of the apartheid ideology in 1982 also saw the UWC assume the reputation as an institution committed to social justice and of being the intellectual home of the left' under the stewardship of Professor Jakes Gerwel in the mid-1980s (Kamola 2016).

\section{South Africa's changing political landscape and the doors opened by the HDI label}

The designation 'HDI' is in recognition of past injustices in the higher education sector and by extension the need for redress by the new democratic state. Following the collapse of apartheid, the plight of HDIs was brought into sharp focus by the new democratic administration after 1994. Through the enactment of the Higher Education Act of 1997, the

\section{http://repository.uwc.ac.za}


new ANC government firmly committed itself to resolving the inequalities and historical injustices facing the 'black' universities. Redressing the disparities between historically privileged and the HDIs formed one the hallmark policies of the Mandela and Mbeki administrations. The change in political dispensation saw universities such as UWC being labelled as 'historically disadvantaged'.

The HDI label has opened doors for funding opportunities which would redress past inequalities. The Higher Education Act 1997, sought to redress the historical disparities between those universities that were deemed as 'white' and those viewed as 'black', largely on the composition of the staff and student populations, respectively.

As the Department of Higher Education formulated its white paper on higher education in 1997, HDIs were left to reflect on what their role would be under the new dispensation. As Morrow $(2008,266)$ notes, '[m] ost HDIs cut free from apartheid leading strings, went through a period of intense crisis, in terms of governance, finance and academic credibility in the mid and late 1990s'. For his part, Subotzsky $(1997,497)$ asserts:

Relative to the proposed national and institutional planning framework, a number of inter-related challenges face South Africa's HBUs. Among these are: redefining their institutional missions and functions; strategically identifying specialized and niche teaching and research programs; academically supporting underprepared students; developing appropriate curricula; promoting quality, effectiveness, and efficiency in all aspects of institutional life; and building academic, planning, and managerial capacity. Additionally, they face difficult financial planning choices under conditions of severe fiscal constraint. Attainment of these goals involves casting off the imprint, orientation, and culture of apartheid, so that HBUs can make an effective contribution to national and regional development.

Many of the challenges faced by HDIs formed the crux of the new government's intervention within the sphere of higher education. For this reason, the Ministerial Committee for the review of funding universities indicated that HDIs generally lag in terms of basic teaching and research infrastructure (DHET 2014). To redress the structural impediments facing HDIs, in October 2013 the Ministerial Committee for the Review of the Funding of Universities made the following recommendations about HDIs:

- The financial dispensation of HDIs has to be improved.

- The DHET should continue to prioritise HDIs in infrastructure development grants.

- A support unit for HDIs should be established.

- The challenges faced by the HDIs in terms of the level of poverty of students and underpreparedness of students need to be addressed by increasing funding allocations.

- At least one DHET-funded centre of research excellence be established.

- A full costing should be done of the backlogs and deficits in the operational costs of HDIs. 
- Universities that have incorporated campuses of former HDIs should receive a special dispensation in the infrastructure and efficiency earmarked grant until infrastructure backlogs at these campuses have been eliminated (DHET 2014, 187-188).

The committee noted that its recommendations would 'not address all of the resourcerelated challenges faced by HDIs'. Suffice to say that HDIs have benefitted immensely from the greater financial and infrastructural investment by the state since the advent of freedom in 1994.

Additionally within the framework of Broad Based Black Economic Empowerment, UWC possesses a fair amount of symbolic capital. This is because a number of the intellectual luminaries from UWC were absorbed into the new ANC-led government in and after 1994. Yet, even in the democratic era, the university faced serious challenges to its identity. In 2002, UWC was earmarked to be merged with the Peninsula Technikon and escaped only after intense lobbying by the Rector at the time, Prof. Brian O'Connell. In an open letter to the 'UWC community', Prof. O'Connell reflected on that time indicating that

Over the last decade the University leadership, staff and students have worked tirelessly to rebuild UWC's reputation as an intellectually rigorous university with the passion and skill to steer the institution on a path of financial recovery. Ten years ago UWC was on the brink of implosion but we succeeded in avoiding a merger with Peninsula Technikon and retaining our glorious struggle history and our name. We also moved from bankruptcy to a stable financial position and, despite the losses of key academic staff members, we managed to rebuild the intellectual leadership of the institution. (O'Connell 2015)

\section{The shackles of the label}

As outlined above, the process of role designation is neither value-free nor a neutral process. In essence, labelling stereotypes the nature of particular being(s), on the basis of real or perceived inherent traits of the subject(s) in question. Prima facie the term historically disadvantaged appears to be an innocuous term to describe past injustice experienced by institutions, particularly educational institutions whose origins were among the historically oppressed demographics under apartheid. At the same time, the label of HDI potentially inhibits opportunities for graduates and has the potential to evoke a set of negative responses among other stakeholders.

These perceptions spill over to students both inside and outside of UWC. Carolissen and Bozalek (2016) in their study of institutional stereotypes interviewed 282 psychology, social work and occupational therapy students from UWC and Stellenbosch University displayed prejudices and stereotypes of their own and other institutions. The following quotes from their study illustrate this:

I would have considered going to UWC had their degrees been recognised internationally. There are majority 'black' and 'coloured' students attending UWC. (White Stellenbosch Psychology student, 2008) 
I know that it's in Bellville and that its acronym is also known as the University of Wild Coloureds. (White Stellenbosch Psychology student, 2008)

In making sense of these perceptions drawn from the longitudinal study on attitudes, Carolissen and Bozalek (2016) assert that

It is crucial to highlight that student mobility and employability in South Africa based on the institution where the degree was obtained is a complex one. UWC is one of the top historically Black institutions in South Africa in terms of teaching and learning and research productivity. Degrees from UWC are internationally recognised but it is a common experience in South Africa, though not well researched, that the everyday discourse of white competence and Black incompetence transfer to institutions like universities and therefore impacts on choice of university, for those who can choose which university to attend. These discourses also impact on potential employers and most Black students are keenly aware of the intersection of the racialized nature of employment opportunities and the university where the degree was obtained. (Carolissen and Bozalek 2016)

This is a situation not unique to UWC. Indeed, Mncayi $(2016,70)$ finds that professional recruiters tend to shun HDIs as they focus their recruitment aims on 'advantaged institutions'. She notes:

Graduate unemployment has also been associated with the Higher Education Institution (HEI) attended, as it was determined that some employers prefer to hire graduates from certain universities because of the trust and confidence they have in the education they provide. In the case of South Africa, traditionally, formerly advantaged universities have been perceived to be provide quality education with higher standards than formerly disadvantaged universities, resulting in employers to hire graduates from the former.

Additionally, a study conducted by the British Council on student perceptions of higher education found that the perception of HDIs among certain employers within the job market negatively affected the prospects of their graduates as they sought entry into the job market. It noted that

Universities still suffer the effects of historical inequalities. These cannot be solved by any one university on its own. Nonetheless, matters of (historical) reputation and advantage and employers' perceptions of reputation can unfairly affect the economic opportunities of students.

The following quotes, adapted from the British Council's report, illustrate students' perceptions of the relationship between institutional reputation and prospects of employment: 
The Wits name implies you are smart ... if you have a Wits degree then you are set. (Wits black female BA/Law student)

I think a student from the University of the Free State would not have the same fair advantage. (UFS white male BSc Geology student)

If you come from Wits ... most of them get employment ... opportunities are greater. Cape Town and Stellenbosch and Wits and so on so, I think they get more opportunities, the companies market themselves more at those universities than they do here. (NMMU, white male Economics student)

In commenting upon the value that students place on their own universities, Carolissen and Bozalek (2016) note, 'social constructions (and hegemonic discourses of higher education institutions have implications for the perpetuation of stereotypes about institutions and consequently, the relative value that students place upon their own and other institutions'. A full understanding of these experiences would require a more rigorous investigation; however, much like insidious racism which can be hard to describe, those who are located in these institutions experience it and understand it.

This of course feeds into the sphere of 'the market' where the HDI label does not have symbolic capital. On the contrary, as students leave the institution and seek employment in the market they may not be imbued with the same cultural and symbolic capital as their counterparts who are exiting historically advantaged or 'white' institutions (see Pauw, Oosthuizen, and Van Der Westhuizen 2008; Moleke 2010; Baldry 2013). This feeds into a perpetuation of the colonial structure and dichotomising system where particular institutions continued to be valued.

\section{Contestation over the legitimate identity of UWC}

An interaction between a media house and one of the authors of this article further illustrates the struggle over what (Bourdieu 1991, 239) terms as the 'monopoly of legitimate naming'. As previously indicated, Bourdieu contends that the 'monopoly of legitimate naming' or the right to confer legitimate identities over agents or subjects is the exclusive preserve of the 'official' or what we understand as authority. In this particular instance, the agent was challenging the assertion of a particular outsider perspective of UWC. In June 2014, long before the start of the \#FeesMustFall protests, a headline on a street light entitled 'UWC - Bush that's burning' could be seen along the streets of Cape Town. It related to internal dynamics at UWC and was accompanied by an article in the Cape Argus entitled 'Rector transformed the former bush college' with the subheading 'Why are some knives out for Rector Brian O'Connell'. The author of the article in the newspaper started out by outlining a series of accomplishments achieved under the leadership of Professor O'Connell, moved to a discussion of internal challenges facing the UWC and ending with the conclusion that 'the university, far from growing into the profile 
of the great institutions of liberal learning, appears to be lurching back to the bush college in its most sinister aspect'.

Here the theories of Stryker and Burke become particularly useful, given the emotive response following what Prof. Africa perceived as a mismatch between her experience at UWC and what was being portrayed in the media. Indeed, she emailed the editors of the media house demanding an apology. In her email, she argued that

To argue that any power struggle, however intense, will nullify our achievements and cause us to lurch backwards is really quite problematic. The author clearly does not understand that the academic project marches on. I have previously written in to this media house and said that I did not want to comment on the merits or demerits of any of the perspectives being aired in the media except to say that UWC, like other institutions, faces a myriad of complex challenges. As I previously indicated I have been a staff member at UWC since 2010. At UWC we continue to provide quality tertiary education to students who would not ordinarily have access to it. Whilst striving to be an institution of excellence, we play a major role in helping to transform South Africa and in reducing the deep inequality which continues to pervade our society. Many of my colleagues passionately share this sentiment. Let me also repeat that UWC is not a perfect place. However, it is where I choose to be ... (Africa 2014)

Prof. Africa argued that the analysis was disparaging and could potentially devalue and damage the academic project. She further argued that the caption on the streetlight poster was particularly problematic because people who said it would not necessarily read the accompanying article. She asked the media house to consider the fact that the person reading the headline might be heading to his or her office to sift through a pile of applications coming from UWC, UCT and Stellenbosch University and that with no other context, that person will have been cued to devalue the qualifications of UWC applicants. She received an immediate response from the editor as well as through an email from the author of the article. Her letter was printed along with an apology (Cape Argus 2014). The newspaper also gave a substantial apology in the form of an editorial comment. She wrote back accepting the apology but took issue with the fact many people know absolutely nothing about UWC will read headlines completely devoid of context and indicated that this could have a real-world impact on UWC graduates entering the job market.

\section{Attempts to shed the connotations of the HDI label}

UWC has actively attempted to shed the negative connotations of label of HDI and locate itself as 'top-tier' institution recognised by various ranking agencies. In 2009, UWC's Senate accepted a Research Policy (University of the Western Cape, n.d.a) which was developed in tandem with UWC's Institutional Operating Plan for the period 2010-2014 (University of the Western Cape 2009) and has been further extended in its 2016-2020 Institutional Operating Plan. The 2016-2020 plan states that 'UWC will be (and will be widely recognised as) a vibrant intellectual space where people engage with matters of real significance at the highest levels of competence' (University of the Western Cape, n.d.b). 
The document further states that 'since the last IOP, UWC has been formally acknowledged as a research-intensive institution, leading the nation in research impact in several spheres'. Indeed, the university has seen an increasing number of academics successfully publish peer-reviewed academic journal articles, books, book chapters as well as in peer-reviewed conference proceedings. The number NRF-rated researchers and SARChI (South African Research Chairs Initiative) Chairs have also increased. UWC currently leads the country in fields such as nanoscience and nanotechnology and has four A-rated scientists in space science (Nkosi 2015). As a result, as of 2016 the university has been ranked as the top university in the realm of physical science by the journal Nature (see Radio 702, 9 September 2016) and seventh best university on the African continent by Times Higher Education (Bothwell 2015).

UWC has also attempted to be a reflexive institution. It has a tradition of reflecting on the history and evolving identity of the university. In particular, former Rector Prof. Brian O'Conell would recount the story of the attempt to merge UWC with the technikons in the province and how we not only managed to retain our identity but positively transformed the institution. Many meetings, student orientation and graduation ceremonies start off by reflecting on the history and identity of the institution. Additionally, the current Deputy Vice Chancellor, Prof. Vivienne Lawack, has launched a project which seeks to grapple with the current identity of UWC and the identity it seeks to create.

UWC's designation as an HDI has become an issue of contestation given the strides that it has made in various areas such as its improved research record. Upon taking office the new Rector of UWC, Prof. Tyrone Pretorius, noted the following:

... And so from finding its soul under Richard van der Ross, defining its intellectual tradition under Jakes Gerwel to the final transformation of UWC into a mature academic project crystallised under Brian O'Connell - who has done sterling work, leading the university from a very weak position to its current prominence as a first-rate institution. O'Connell's cardinal role in securing state-of-the-art buildings and facilities has depended on the acknowledged importance and quality of the academic work being done. That is wonderful. But I need to tell you that Professor O'Connell has also created an awkward dilemma. Many historically advantaged institutions feel entitled to the best and view high-end resources spent on HDIs as wasted. Conversely, most HDIs tend to argue that it is now their turn for redress and that universities which have 'arrived', like UWC, should receive less state funding, which should rather be spent on boosting their capacity. (Independent Online 2015)

The recognition that the university has received has put the university in a precarious situation regards to its 'positionality' within the broader field of higher education in South Africa. Indeed, Kraak $(2009,142)$ identifies UWC as a 'formerly disadvantaged institution' implying that the institution has developed to such extent so as to warrant a different designation from historically disadvantaged. 
This 'new status', as it was belies the fact that the institution still experiences a number of challenges in the way of infrastructure and overall institutional development. This is a fact that is acknowledged by the University's Vice Chancellor, Professor Tyrone Pretorius.

He states 'we're the only historically disadvantaged institution now playing in the premier league'. He further noted:

UWC being better off actually poses a dilemma for us because our achievements place us among the top universities in South Africa. Our dilemma is, even though we have achieved that, we're still historically disadvantaged. We still don't have the reserves that other institutions have that are advantaged. (Nkosi 2015)

Many students at UWC have dire circumstances (social, physical, economic and psychological) which suggest that they require ongoing support throughout the academic year. The physical location of the university adds to these challenges. Staff and departments often have to choose between competing and equally urgent priorities. In an interview with the Mail and Guardian, Prof. Pretorius noted the following:

We face so many challenges in thinking about UWC's future. We really have serious challenges. We struggle with providing our students with the most basic technology in this digital age. Our staff [to] student ratio is absurd. It's so high, it's absurd. We have infrastructure problems. We don't have sufficient space for students in residences. (Nkosi 2015)

The fact of the matter is that despite its achievements in research, staff members at UWC face many competing demands due to the high student to staff ratio as well as other logistical challenges around funding and infrastructure. While these challenges are certainly not unique to UWC or even to HDIs, many of these challenges do in fact emanate from the disparate allocation of resources under the previous dispensation.

\section{Grappling with the label: the need for a new language}

UWC has not been a passive recipient of its designation. It has a long history of wrestling with the role ascribed to it. Wolpe $(1995,283)$ asserts that UWC repudiated the politicalideological grounds on which it was established rejecting the role ascribed to it by the state as an instrument for the reproduction of apartheid - the separate and unequal position of the coloured people - and of the ascription of the university as 'coloured'. Wolpe adds that the university also rejected an instrumental role in the maintenance and reproduction of the apartheid system. Today in a democratic dispensation UWC is again grappling with its role, however now it is not quite as simple. The complexity of the matter is compounded by the fact that the state as well as sponsors and prospective employers have power to provide or withhold opportunities and resources based on aming. There is an incentive to shed the label when dealing with sponsors and prospective employers and to retain the label when dealing with the state. Unlike individuals who, according to Stryker and Burke, can hold multiple identities with different roles embedded in one or

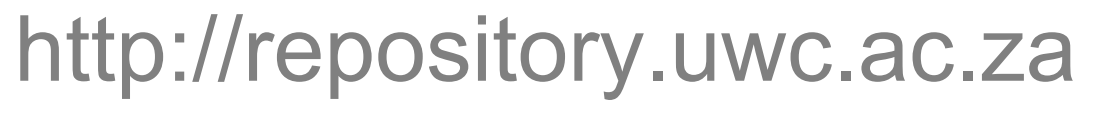


more groups that provide context for the meanings and expectations associated with that role, institutions are typically expected to choose and embrace a particular identity.

There are implications stemming from the existing categorisation of South Africa's universities. The term HDI is used by the state, and universities are beneficiaries of state support under that label. Retaining the label recognises the immense challenges that such institutions have overcome and it provides access to much needed resources. Their identification as historically underprivileged tertiary educational institutions has afforded these institutions financial support through which they can develop their infrastructure and overall institutional capacity. Institutions therefore need the label because it provides access to much-needed resources and because the playing fields have not been levelled.

At the same time, the label carries a stigma that has the potential to impact negatively on the institution. The very designation of being an HDI has ironically had an impact on the ability of these institutions to dispel the perceptions of them as being second-tier institutions of higher learning, particularly in the eyes of potential employers and donors. This evokes negative emotion and raises questions about how to admit to institutional challenges and still shed the label. The label also has the potential to inhibit the institutional transformation of higher education institutions within this category as it highlights historical disadvantages while concealing subsequent developmental achievements. On the other hand, removing the term HDI, so as to recognise the gains being made by these institutions, is also problematic because it does not take cognisance of their continuing challenges that emanate from their historical roots and removes the rationale for continued state support.

The situation that the UWC finds itself in and the issues raised in this article are likely to be pertinent for other HDIs as well.

What then is the route out of this conundrum? This is a complex issue. Indeed Matthews (2018) who engages with Mudimbe's concept of the 'colonial library' to contribute to current debates about decolonising South African university curricula indicates that 'a distinctive contribution that Mudimbe makes to such discussions is his rather devastating claim that attempts to resist the colonial library remain at least partially beholden to it'. She notes Mudimbe's argument that, many African scholars end up using 'categories and conceptual systems that depend on a Western epistemological order' even as they resist the colonial library. However, rather than accepting Mudimbe's rather depressing view that it is futile to resist the colonial library because of the deep embeddedness of these constructs, we believe that it is time to open the conversation about institutional labelling, othering and how we can move beyond the binaries that have been created. Instead of forcing institutions into an untenable choice, we need to look at creating a new terminology that acknowledges history without perpetuating stigma. Much like the difference between a victim and a survivor, we need terminology that recognises the historical contexts of HDIs but liberates them from the connotation of inferiority 
and acknowledges achievements. There needs to be a way to recognise the complexity of institutional identities which takes into account issues of power and the real-world implications of that naming process. It should also recognise the crucial challenges that still remain with regard to the funding of higher education and the need to move towards equity between institutions.

\section{Acknowledgements}

We would like to thank the initial reviewers of the article for their valuable insights into the first draft. It should be noted that the perspective of this article is shaped by the personal experiences of the authors. Prof. Africa has worked at UWC since 2010 and Dr MutizwaMangiza has worked at University of Fort Hare and is now based at UWC. Acknowledging that there are multiple experiences of UWC, the modest intention of this article is to open a conversation about the impact and experience of institutional labelling.

\section{Disclosure statement}

No potential conflict of interest was reported by the authors

\section{Funding}

This work was made possible through the generous support of the Andrew W. Mellon Foundation [grant number 41500689]. 


\section{References}

Africa, C. 2014. "Academic Work Moves On - Despite UWC Challenges." Cape Argus, June 9, p. 22. Baldry, K. 2013. "Graduate Unemployment in South Africa: Prevalence, Characteristics and Perceived Causes." MA diss., Johannesburg: University of the Witwatersrand.

Becker, H. 1963. Outsiders: Studies in Sociology of Deviance. New York: Free Press.

Bothwell, E. 2015. "Top 30 African Universities: Times Higher Education Reveals Snapshot University Ranking." Accessed December 1, 2017. https://www.timeshighereducation.com/news/top-30-african-universities-timeshigher-education-reveals-snapshot-university-ranking.

Bourdieu, P. 1991. Language and Symbolic Power. Oxford: Polity Press \& Basil Blackwell. Cape Argus. 2014. "No Offence Meant." June 9, p. 20.

Carolissen, R., and V. Bozalek. 2016. "Addressing Dualisms in Student Perceptions of a Historically White and Black University in South Africa." Race Ethnicity and Education 20 (3): 344-357.

Cooper, D., and G. Subotzky. 2001. The Skewed Revolution: Trends in South African Higher Education 1988-1998. Cape Town: CSHE.

Department of Higher Education and Training. 2014. Report for the Ministerial Committee for the Review of the Funding of Universities. Department of Higher Education and Training. Accessed July 16, 2017. http://www.dhet.gov.za/Financial\%20and\%2oPhysical\%2oPlanning/Report\%20of\% 20the\%2oMinisterial\%2oCommittee\%2ofor\%2othe\%2oReview\%20of\%2othe\%20Fu nding\%20of\%2oUniversities.pdf.

Independent Online. 2015. "UWC Striving to Be Fully Connected." Cape Times, February 17. Accessed December 1, 2017. https://www.iol.co.za/capetimes/opinion/uwc-strivingto-be-fully-connected- 1819225\#.VV2tQkY-WWo.

Kamola, I. 2016. "The Global University in South Africa." In The Transnational Politics of Higher Education, edited by M. H. Chou, I. Kamola, and T. Pietsch, 42-62. New York: Routledge.

Kraak, A. 2009. "South Africa's Elite Universities in the Post-Apartheid Era, 1994-2007." In Structuring Mass Higher Education: The Role of Elite Institutions, edited by D. Palfreyman and T. Tapper, 129-152. New York: Routledge Press.

Lemert, E. M. 1974. "Beyond Mead: The Societal Reaction to Deviance." Social Problems 21 (4): 457-468.

Matthews, S. 2018. "Confronting the Colonial Library: Teaching Political Studies Amidst Calls for a Decolonised Curriculum." Politikon 45 doi:10.1080/02589346.2018.1418204.

Mncayi, P. 2016. "An Analysis of the Perceptions of Graduate Unemployment Among Graduates from a South African University." International Journal of Social Sciences and Humanity Studies 8 (1): 67-83.

Moleke, P. 2010. "The Graduate Labour Market." In Student Retention and Graduate Destination: Higher Education and Labour Market Access and Success, edited by Letseka et al., 1-20. Cape Town: HSRC Press. 
Morrow, S. 2008. "Race, Redress and Historically Black Universities." In Racial Redress and Citizenship, edited by A. Habib and K. Bentley, 263-288. Cape Town: Human Sciences Research Council.

Mudimbe, V. Y. 1988. The Invention of Africa: Gnosis, Philosophy, and the Order of Knowledge. Bloomington: Indiana University Press.

Nkosi, B. 2015. "UWC's Success Counts Against It." Mail and Guardian, May 22. Accessed 29,

November 2017. https://mg.co.za/article/2015-05-22-uwcs-success-counts-against-it.

O'Connell, B. 2015. "Open Letter to the University of the Western Cape Campus Community." Accessed November 30, 2017. http://www.mediaweb.co.za/mediarelease/OPEN-LETTER-TO-THE-UNIVERSITY-OF-THE-WESTERN-CAPECAMPUS-COMMUNITY.

Pauw, K., M. Oosthuizen, and C. Van Der Westhuizen. 2008. "Graduate Unemployment in the Face of Skills Shortage: A Labour Market Paradox." South African Journal of Economics 6 (1): 45-57.

Rosenthal, R., L. Jacobson, and M. Deutsch. 1968. Social Class, Race and Psychological Development. New York: Holt, Rinehart and Winston.

Stryker, S., and P. Burke, 2000. "The Past, Present, and Future of an Identity Theory." Social Psychology Quarterly 63 (4): 284-297.

Subotzsky, G. 1997. "Redefining Equity: Challenges and Opportunities Facing South Africa's Historically Black Universitites Relative to Global and National Change." The Journal of Negro Education 66 (4): 496-521.

University of the Western Cape. 2009. "Institutional Operating Plan (2010-2014)." University of the Western Cape. Accessed December 1, 2017. https://www.uwc.ac.za/SO/HR/Documents/IOP-\% 20the\%20now.pdf.

University of the Western Cape. n.d.a. "Research and Development." Accessed November 30, 2017. https://www.uwc.ac.za/Research/Pages/default.aspx\#.

University of the Western Cape. n.d.b. "Institutional Operating Plan 2016-2020: White Paper.” Accessed December 2017. https://ikamva.uwc.ac.za/content/whitepaper.pdf.

Wolpe, H. 1995. "The Debate on University Transformation in South Africa: The Case of the University of the Western Cape." Comparative Education 31 (2): 275-292.

Wood, G. 1985. Labelling in Development Policy. London: Sage. 